\title{
Hydraulic Conductance in Susceptible versus Tolerant Peach Seedlings Infected with Leucostoma persoonii
}

\author{
L.S. Chang, ${ }^{1}$ A.F. Iezzoni, ${ }^{2}$ G.C. Adams, ${ }^{3}$ and F.W. Ewers ${ }^{3}$ \\ Michigan State University, East Lansing, MI 48824 \\ Additional index words. Cytospora canker, perennial canker, Prunus persica
}

\begin{abstract}
Eight open-pollinated peach families [Prunus persica (L.) Batsch] were selected from a germplasm collection that was screened for tolerance to Leucostoma persoonii (Nits.) Höhn. [imperfect state, .Leucocytospora leucostoma (Pers.) Höhn] following field inoculation. The eight peach families were either susceptible or tolerant to L. persoonii infection based on canker length measurements. Three open-pollinated seedlings per family were chosen for evaluation. Following artificial inoculation, measurements of hydraulic conductance per pressure gradient $\left(K_{h}\right)$ were made on 2 year-old branch segments from the 24 seedlings, and safranin dye was used to mark the conductive xylem pathways. For the peach families tolerant to L. persoonii, the specific $K_{\mathrm{h}}$ of the canker branch segments was greater than that for the most susceptible peach families. The inoculated branch segments from the tolerant peach families maintained $\approx 15 \%$ to $30 \%$ of the water transport of control segments. Safranin dye movement indicated that the sapwood in inoculated branch segments of seedlings from the susceptible peach families was almost completely blocked. Isolation experiments indicated deeper penetration of the fungus into the xylem of seedlings of susceptible than tolerant families. Xylem dysfunction appears to be correlated with a reduction in $K_{h}$, and the seedlings in the tolerant peach families are better able to maintain water transport through the stem segment invaded by the fungus.
\end{abstract}

In the 1950s, peach orchards in the northeastern United States were expected to remain productive for at least 30 years. Now, the life of a peach orchard averages $\leq 15$ years (Mich. Orchard and Vineyard Survey, 1986). Cytospora canker, caused by Leucostoma persoonii and L cincta (Fr. ) Höhn. [imperfect state, Leucocytospora cincta (Sacc.) Höhn.], is one of the most serious diseases reducing peach tree life in the central and northern United States (Gairola and Powell, 1970; Hildebrand, 1947; Jones and Leupschen, 1971; Luepschen, 1981; Luepschen et al., 1975) and in the eastern peach growing regions of Canada (Cline, 1982; Layne, 1976; Wensley, 1964).

Histopathological investigations of $L$. persoonii classified the canker pathogen as a facultative bark parasite (Biggs, 1984, 1986a, 1986b; Biggs and Stobbs, 1986; Wisniewski et al., 1984) or as a sapwood parasite (Banko and Helton, 1974; Tekauz and Patrick, 1974). These histopathological investigations concentrated on fungal growth in the bark. However, if the pathogen grew beyond the bark and into the xylem, there could be a noticeable reduction in water transport measured as $K_{h} \cdot K_{h}$ is the measured flow rate of a fluid divided by the pressure gradient. Reductions in $\mathrm{K}_{\mathrm{h}}$ have been associated with death of branches in American chestnut blight (Ewers et al., 1989) and peach phony disease (Evert, 1987). Hampson and Sinclair (1973) inoculated five peach cultivars grown in a greenhouse with $L$. persoonii and reported that pathogen infection reduced the xylem function in all inoculated cultivars in comparisons with uninoculated healthy plants. However, there were no significant differences among these peach cultivars for xylem dysfunction.

Recently, peach families tolerant to $L$. persoonii following

Received for publication 12 July 1990. Acknowledgement is made to the Michigan Agricultural Experiment Station for their support of this research. Funded in part by USDA Contract no. 88-34152-3380 to A.F.I. The cost of publishing this paper was defrayed in part by the payment of page charges. Under postal regulations, this paper therefore must be hereby marked advertisement solely to indicate this fact.

'Dept. of Horticulture. Current address: National Taiwan Univ., Taipei, Taiwan, R.O.C.

${ }^{2}$ Dept. of Horticulture.

${ }^{3}$ Dept. of Botany and Plant Pathology. field inoculation were identified (Chang et al., 1989). The objective of our work was to determine if xylem dysfunction was associated with susceptibility to L. persoonii. In addition to $\mathrm{K}_{\mathrm{h}}$ measurements, branch segments were sectioned and L. persoorrii isolations were made to determine the depth of invasion of the fungus into the wood.

\section{Materials and Methods}

In Spring 1984, 653 open-pollinated peach seedlings from 15 peach clones, two peach x $\boldsymbol{P}$. kansuensis hybrids, and one peach $\times$ almond ( $\boldsymbol{P}$. dulcis Webb) hybrid were planted in a completely randomized design at the Horticultural Research Center, East Lansing, Mich. These seedlings, representing half-sib families, were evaluated twice for length of canker necrotic tissue following inoculation of 2-year-old branches with $L$. persoonii. Branches were inoculated, using the technique developed by Scorza and Pusey (1984), for two experiments in Oct. 1986 and 1987 that then were evaluated in May of the following years. Two branches per seedling were each inoculated with $20 \mu \mathrm{l}$ of a suspension of $10^{7} \mathrm{~L}$. persoonii conidia/ml. The conidia were derived from a mixture of two isolates, one (MI R-1) collected in Hartford, Mich., and the other (MI 11.13) in Clarksville, Mich. (Adams et al., 1989). The following May, during budbreak, canker necrotic length was measured as the length of the necrotic area distal to the point of inoculation. Additionally, inoculated branches were rated visually for canker infection using a scale of $0=$ dead, 1 = severe wilting of expanding leaves, 2 = weak growth and slight wilting of expanding leaves, and $3=$ healthy. Since the canker ratings are nonparametric data, the Kruskal and Wallis test based on ranking observations from largest to smallest (Steel and Torrie, 1960) was used to test for significant differences among families. In the Kruskal and Wallis test, the null hypothesis is that the populations have the same mean.

Following the field inoculation experiments with L. persoonii, eight open-pollinated peach families were selected that

Abbreviations: $K_{h}$, hydraulic conductance per pressure gradient. 
were previously rated as susceptible or tolerant to $L$. persoonii (Chang et al., 1989). $\mathrm{K}_{\mathrm{h}}$ measurements were made on branches from three seedlings chosen at random from each of the eight families. Two branches per seedling were each inoculated with $20 \mu \mathrm{l}$ of a suspension of $10^{6} \mathrm{~L}$. persoonii conidia/ml in Oct. 1986 as described by Chang et al., (1989). Two healthy branches within each tree were used as the noninoculated controls. Branches were collected between 0700 and 0800 HR the following May, and the basal ends were immediately immersed in water and recut under water to minimize the introduction of embolisms. To reduce lateral transport of water, lateral twigs were removed from the branches and wounds were immediately sealed with fingernail polish. The branches were trimmed to $\approx 0.25 \mathrm{~m}$ in the laboratory and stored $12 \mathrm{~h}$ under water at room temperature. A separate series of experiments showed that storage had no effect on $\mathrm{K}_{\mathrm{h}}$ for $24 \mathrm{~h}$. Both ends of each branch segment were shaved with a new razor blade until smooth. Vinyl tubing was then firmly clamped to the distal end. The stem surface was vacuum infiltrated with filtered $0.1 \mathrm{M}$ oxalic acid, $\mathrm{pH} 2.0$ at - $87 \mathrm{kPa}$ for $5 \mathrm{~min}$ before the conductivity measurement. Filtered oxalic acid was used to minimize possible artifacts caused by microbial growth in the fluid (Sperry et al., 1988). Pressure of $5 \mathrm{kPa}$ was applied with a distilled water column and the rate of flow measured with a stopwatch and pipet (Zimmerman, 1978). $\mathrm{K}_{\mathrm{h}}=\left(\right.$ the rate of flow in $\left.\mathrm{m}^{3} \cdot \mathrm{s}^{-1}\right) /($ applied pressure gradient in $\left.\mathrm{MPa} \cdot \mathrm{m}^{-1}\right)$. All $\mathrm{K}_{\mathrm{h}}$ measurements were done within 12 $\mathrm{h}$ of the initial collection time. Three readings were used to calculate a mean $\mathrm{K}_{\mathrm{h}}$ of each stem segment. Specific conductivity ( specific $\mathrm{K}_{\mathrm{h}}$ ) $=\mathrm{K}_{\mathrm{h}}$ /cross-sectional area. Percent specific $\mathrm{K}_{\mathrm{h}}=$ (specific $\mathrm{K}$, of the inoculated branch segments)/(specific $\mathrm{K}_{\mathrm{h}}$ of the control stem segments) 100 .

Canker necrotic length, specific $K_{h}$, and percent specific $K_{h}$ were analyzed in a nested design with the following sources of variation: family, seedling within family, and branch within seedling.

Safranin-O dye $(0.5 \%)$ was poured into the vinyl tube immediately after finishing $\mathrm{K}_{\mathrm{h}}$ measurements. The height of the dye in the tubes was kept constant $(0.5 \mathrm{~m})$ for each branch segment for $1.5 \mathrm{~h}$. The dye marked the xylem vessels capable of water transport. The hydroconductivity experiment was repeated the following year.

L. persoonii in the wood was isolated to determine the depth and degree of the fungal invasion. The branch segments containing the inoculated wound were trimmed to 6-mm lengths, debarked, and surface sterilized with $95 \%$ ethanol. Longitudinal sections of wood ( $1 \mathrm{~mm}$ deep) were excised beginning at the surface margins of necrosis and proceeding inward to the pith and beyond, through the stem, in 1-mm increments. The 1-mm sections of tissue layers were placed on Leonian's agar medium (Leonian, 1921). The culture plates were incubated at 25C under cool-white fluorescent light for 2 weeks and scored for the presence of $L$. persoonii.

\section{Results and Discussion}

Field inoculations in Fall 1986 and 1987 revealed significant differences among the peach families both in canker necrotic length and canker rating in response to $L$. persoonii infection. The open-pollinated 'Yennoh' progeny (numbered 1-31, 1-39, and 4-11) and open-pollinated NJ672017002 progeny (numbered 1-8, 2-32, and 4-16) had the shortest longitudinal length of necrosis (cankers) following inoculation and the highest rating (Table 1). These families were considered the most tolerant. Dhanvantari and Dirks (1983) found that linear canker extension
Table 1. Mean values for $L$. persoonii canker length and canker ratings in May following artificial inoculations in Fall 1986 and 1987 of open-pollinated seedlings of eight peach selections. ${ }^{z, y}$

\begin{tabular}{|c|c|c|c|c|}
\hline \multirow[b]{2}{*}{ Parent } & \multicolumn{2}{|c|}{$\begin{array}{l}\text { Canker necrotic } \\
\text { length }(\mathrm{cm})\end{array}$} & \multicolumn{2}{|c|}{$\begin{array}{c}\text { Canker } \\
\text { ratings }\end{array}$} \\
\hline & 1986 & 1987 & 1986 & 1987 \\
\hline $\begin{array}{l}\text { Loring } \\
\quad(2-7,11-27,11-32) \\
\text { Elberta }\end{array}$ & $15.7 \mathrm{a}$ & $19.0 \mathrm{a}$ & 0.0 & 1.7 \\
\hline $\begin{array}{l}(6-32,11-34,11-38) \\
\text { Canadian Harmony }\end{array}$ & $17.0 \mathrm{a}$ & $11.8 \mathrm{ab}$ & 0.0 & 1.0 \\
\hline $\begin{array}{l}\quad(3-17,3-20,5-9) \\
\text { Harken }\end{array}$ & $13.1 \mathrm{abc}$ & $8.7 \mathrm{~cd}$ & 0.5 & 1.7 \\
\hline $\begin{array}{l}(2-6,2-29,2-44) \\
\text { Reliance }\end{array}$ & $11.6 \mathrm{abc}$ & $15.0 \mathrm{ab}$ & 0.5 & 1.7 \\
\hline $\begin{array}{l}\quad(1-33,1-41,15-16) \\
\text { Babygold } 8\end{array}$ & $13.8 \mathrm{ab}$ & $7.8 \mathrm{cde}$ & 0.3 & 0.8 \\
\hline $\begin{array}{l}(2-13,2-14,3-10) \\
\text { NJ672017002 }\end{array}$ & $12.8 \mathrm{abc}$ & $11.2 \mathrm{bc}$ & 0.5 & 1.0 \\
\hline $\begin{array}{l}(1-8,2-32,4-16) \\
\text { Yennoh }\end{array}$ & $7.0 \mathrm{c}$ & $5.4 \mathrm{de}$ & 2.3 & 3.0 \\
\hline$(1-31,1-39,4-11)$ & $7.1 \mathrm{bc}$ & $3.2 \mathrm{e}$ & 2.5 & 3.0 \\
\hline
\end{tabular}

${ }^{2}$ Data are the mean of two branches from each of three seedlings per selection.

'Means followed by different letters are significantly different according to LSD at 0.05 level.

${ }^{x}$ Canker rating is $0=$ dead, $1=$ severe wilting of expanding leaves, 2 = weak growth and slight wilting of expanding leaves, and $3=$ healthy.

wAll populations do not have the same mean according to the Kruskal and Wallis test at the 1\% level (Steel and Torrie, 1960).

following artificial inoculation with Leucostoma was related to visual ratings of the incidence of naturally induced cankers during 10 years.

Specific $\mathrm{K}_{\mathrm{h}}$ and percent specific $\mathrm{K}_{\mathrm{h}}$ differed significantly among the eight peach families (Table 2). The specific $K_{h}$ and percent specific $K_{h}$ tended to be higher for the more tolerant than for the more susceptible peach families. The percent specific $K_{h}$ was significantly correlated with the canker necrotic length and canker rating ( $r=0.74$ and 0.75 , respectively). The longer the canker necrotic length, the less water was capable of being transported, and the more severe was the wilting. This result suggested that the tolerant plants were able to transport more water through the infected zone than the susceptible plants. This ability could explain why branches from the tolerant seedlings remained healthy 7 months after inoculation and infection.

The variation in specific $\mathrm{K}_{\mathrm{h}}$ and percent specific $\mathrm{K}_{\mathrm{h}}$ was quite large and probably could be attributed to experimental variation in the size, age, and vigor of the plants plus genetic variation among the three seedlings per family. For example, the 1988 percent specific $\mathrm{K}_{\mathrm{h}}$ means for Yennoh 1-31, 1-39, and 4-11 were $30.0 \%, 37.5 \%$, and $33.5 \%$, respectively. Likewise, the 1988 percent specific $\mathrm{K}_{\mathrm{h}}$ means for NJ672017002 1-8, 2-32, 416 were $32.0 \%, 16.0 \%$, and $15.5 \%$, respectively. Yennoh 139 and NJ672017002 1-8 had previously been identified in the germplasm population as the most tolerant seedlings.

Fewer vessel elements were stained with safranin-O in the inoculated branches than in the noninoculated controls (Fig. 1). The extent of xylem dysfunction following inoculation was less in the tolerant seedlings than in susceptible seedlings. In susceptible seedlings, the outer xylem ring was nonconductive, while in the more tolerant seedlings the outer and some of the inner xylem vessels were conductive. Since branches had been 
Table 2. Specific $\mathrm{K}_{\mathrm{h}}{ }^{\mathrm{z}}$ and percent specific $\mathrm{K}_{\mathrm{h}}{ }^{\mathrm{y}}$ for Leucostoma canker infection following artificial inoculations in Fall 1986 and 1987 of open-pollinated seedlings of peach.,

\begin{tabular}{|c|c|c|c|c|}
\hline \multirow[b]{2}{*}{ Parent } & \multicolumn{2}{|c|}{ Specific $K_{h}$} & \multicolumn{2}{|c|}{ Percent specific $\mathrm{K}_{\mathrm{h}}$} \\
\hline & 1986 & 1987 & 1986 & 1987 \\
\hline $\begin{array}{l}\text { Loring } \\
\quad(2-7,11-27,11-32) \\
\text { Elberta }\end{array}$ & $0.58 \mathrm{c}$ & $1.02 \mathrm{~b}$ & $5.9 \mathrm{~cd}$ & $8.8 \mathrm{bc}$ \\
\hline $\begin{array}{l}(6-32,11-34,11-38) \\
\text { Canadian Harmony }\end{array}$ & $0.92 \mathrm{bc}$ & $1.52 \mathrm{ab}$ & $6.0 \mathrm{~cd}$ & $17.9 \mathrm{bc}$ \\
\hline $\begin{array}{l}(3-17,3=20,5-9) \\
\text { Harken }\end{array}$ & $1.81 \mathrm{abc}$ & $0.78 \mathrm{~b}$ & $14.2 \mathrm{abcd}$ & $5.9 \mathrm{c}$ \\
\hline $\begin{array}{l}(2-6,2-29,2-44) \\
\text { Reliance }\end{array}$ & $0.63 \mathrm{c}$ & $0.82 \mathrm{~b}$ & $5.4 \mathrm{~d}$ & $11.4 \mathrm{bc}$ \\
\hline $\begin{array}{l}(1-33,1-41,15-16) \\
\text { Babygold } 8\end{array}$ & $1.18 \mathrm{bc}$ & $0.93 \mathrm{~b}$ & $10.9 \mathrm{bcd}$ & $11.8 \mathrm{bc}$ \\
\hline $\begin{array}{l}(2-13,2-14,3-10) \\
\text { NJ672017002 }\end{array}$ & $1.81 \mathrm{abc}$ & $2.81 \mathrm{ab}$ & $20.3 \mathrm{a}$ & $20.7 \mathrm{ab}$ \\
\hline $\begin{array}{l}(1-8,2-32,4-16) \\
\text { Yennoh }\end{array}$ & $3.10 \mathrm{a}$ & $3.44 \mathrm{a}$ & $15.2 \mathrm{abc}$ & $21.4 \mathrm{ab}$ \\
\hline$(1-31,1-39,4-11)$ & $2.48 \mathrm{ab}$ & $3.16 \mathrm{a}$ & $18.5 \mathrm{ab}$ & $33.9 \mathrm{a}$ \\
\hline
\end{tabular}

${ }^{2}$ Specific $\mathrm{K}_{\mathrm{h}}=$ volume [(flow in $\left.\mathrm{m}^{3} \cdot \mathrm{s}^{-1}\right)$ /applied pressure gradient in MPa per $\mathrm{m}$ of stem length)]/cross-sectional area of the stem in $\mathrm{m}^{2}$. yPercent specific $K_{h}=$ (specific $K_{h}$ of inoculated branch)/(the control branch) 100 .

xData are the mean of two branches from each of three seedlings per selection.

wMeans followed by the same letters are not significantly different according to LSD at 0.05 level.

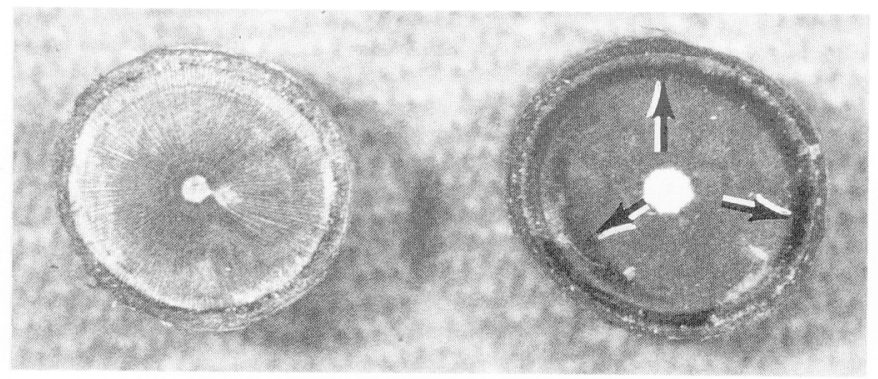

Fig. 1. Transverse sections of a pair of peach branches used for hydraulic conductance measurements of Canadian Harmony (3-17). Left: branch was inoculated with L pemoonii; right: uninoculated control. Stained xylem (arrows) indicate safranin-O (0.570) movement through the functional xylem. The xylem in the inoculated branch was nonfunctional.

inoculated in October and evaluated in the following May, the presence of conductive xylem vessels would become critical during the growing period.

Above the necrotic zone of $L$. persoonii infection, $\mathrm{K}_{\mathrm{h}}$, specific $\mathrm{K}_{\mathrm{h}}$, and quantity of dyed xylem vessels were equivalent in control and in inoculated branches (data not presented). Vessel blockage was apparently localized around the infected canker area; therefore, wilting symptoms were not likely due to transport of fungal toxins.

To understand the involvement of the L. persoonii fungus in disrupting xylem flow, we determined the depth of $L$. persoonii invasion into the xylem. In susceptible families, it was possible to isolate the fungus from the margin of the surface necrosis down to the pith of the branch. For the tolerant families, the fungus was isolated only as deep as the secondary layer $(\approx 2$ $\mathrm{mm}$ ) beneath the margin of the surface necrosis. Percent infection was calculated as the percentage of 1-mm sections per in-
Table 3. Percent of 1-mm sections per inoculated stem from which L. persoonii was reisolated for open-pollinated seedlings of peach.

\begin{tabular}{lc}
\hline \hline \multicolumn{1}{c}{$\begin{array}{c}\text { Parent } \\
\text { (open-pollinated seedlings) }\end{array}$} & $\begin{array}{c}\text { Infection }^{2} \\
(\%)\end{array}$ \\
\hline Loring $(2-7,11-27-32)$ & 90 \\
Elberta $(6-32,11-34,11-38)$ & 71 \\
Canadian Harmony (3-17, 3-20, 5-9) & 97 \\
Harken (2-6, 2-29, 2-44) & 95 \\
Reliance $(1-33,1-41,15-16)$ & 70 \\
Babygold 8 (2-13, 2-14, 3-10) & 20 \\
NJ672017002 (1-8, 2-32, 4-16) & 9 \\
Yennoh $(1-31,1-39,4-11)$ & 5 \\
\hline
\end{tabular}

${ }^{2}$ Data are the mean of three seedlings per selection.

oculated branch from which L. persoonii was reisolated. Tolerant seedlings had $<10 \%$ infected branch sections; however, the susceptible ones ranged from $20 \%$ to $90 \%$ infected branch sections (Table 3). The lack of penetration of the fungus through the wood of seedlings from tolerant families suggests that xylem characteristics of Yennoh and NJ672017002 seedlings limit the advance of the pathogen.

In conclusion, xylem dysfunction following L. persoonii infection of susceptible seedlings was associated with wilting and death of branches. The canker pathogen invaded the xylem in the susceptible peach seedlings and significantly reduced $\mathrm{K}_{\mathrm{n}}$ through the infection zone. In the tolerant seedlings, the xylem remained functional following branch inoculation, perhaps because of reduced penetration by the fungus. Therefore, the tolerant seedlings are able to maintain adequate water transport through the necrotic canker zone during the summer following inoculation. The actual cause of branch death in susceptible seedlings still needs further study because both xylem and phloem are damaged by the pathogen.

\section{Literature Cited}

Adams, G. C., S.A. Hammar, and A.F. Iezzoni. 1989. Optimum sample size for detecting differences in Leucostoma isolates from peach. Plant Dis. 73:754-759.

Banko, T.J. and Helton, A.W. 1974. Cytospora-induced changes in stems of Prunus persica. Phytopathology. 64:899-901.

Biggs, A.R. 1984. Boundary-zone formation in peach bark in response to wounds and Cytospora leucostoma infection. Can. J. Bet. 6228142821.

Biggs, A.R. 1986a. Wound age and infection of peach bark by Cytospora leucostoma. Can. J. Bot. 64:2319-2321.

Biggs, A.R. 1986b. Comparative anatomy and host response to two peach cultivars inoculated with Leucostoma cincta and L. persoonii. Phytopathology 76:905-912.

Biggs, A.R. and L.W. Stobbs. 1986. Fine structure of the suberized cell walls in the boundary zone and necrophylactic periderrn in wounded peach bark. Can. J. Bet. 64:1606-1610.

Chang, L. S., A. Iezzoni, G. Adams, and G.S. Howell. 1989. Leucostoma tolerance and cold hardiness among diverse peach genotypes. J. Amer. Soc. Hort. Sci. 114:482485.

Cline, R.A. 1982. Cultural practices in peach canker development in Ontario. Proc. Stone Fruit Decline Workshop, Mich. State Univ., East Lansing, Mich. 18-20 Oct. 1982. p. 30-33.

Dhanvantari, B.N. and V.A. Dirks. 1983. An evaluation of peach cultivars and selections for resistance to Leacostoma cincta. Can. J. Plant Sci. 63:307-310.

Evert, D.R. 1987. Influence of phony disease of peach on stem hydraulic conductivity and leaf xylem pressure potential. J. Amer. Soc.Hort. Sci. 112:1032-1036.

Ewers, F. W., P.S. McManus, A. Goldman, R. Gucci, and D.W. Fulbright. 1989. The effect of virulent and hypovirulent strains of $E n$ - 
dothia parasitic on hydraulic conductance in American chestnut. Can. J. Bet. 67:1402-1407.

Gairola, C. and D. Powell. 1970. Cytospora canker in Illinois. Plant Dis. Rptr. 54:832-835.

Hampson, M.C. and W.A. Sinclair. 1973. Xylem dysfunction in peach caused by Cytospora leucostoma. Phytopathology 63:676-681.

Hildebrand, E.M. 1947. Perennial peach canker and the canker complex in New York with methods of control. Cornell Univ. Agr. Expt. Sta. Memoir 276:5-61.

Jones, A.C. and N.S. Luepschen. 1971. Seasonal development of Cytospora canker on peach in Colorado. Plant Dis. Rptr. 55:314-317.

Layne, R.E.C. 1976. Influence of peach seedling rootstocks on perennial canker of peach. HortScience 11:509-511.

Leonian, L.H. 1921. Studies on the Valsa apple canker in New Mexico. Phytopathology 11:236-243.

Luepschen, N.S. 1981. Criteria for determining peach variety susceptibility to Cytospora canker. Fruit Var. J. 35:137-140.

Luepschen, N. S., K.G. Rohrback, A.C. Jones, and L.E. Dickens. 1975. Susceptibility of peach cultivars to Cytospora canker under Colorado orchard conditions. HortScience 10:76-77.
Michigan Orchard and Vineyard Survey. 1986. Mich. Dept. Agr., Mich. Agr. Stat. Serv., Lansing.

Scorza, R. and P.L. Pusey. 1984. A wound-freezing inoculation technique for evaluating resistance to Cytospora leucostoma in young peach trees. Phytopathology 74:569-572.

Sperry, J. S., J.R. Donnelly, and M.T. Tyree. 1988. A method for measuring hydraulic conductivity and embolism in xylem. Plant Cell Env. 11:3540.

Steel, R.G.D. and J.H. Torrie. 1960. Principles and procedures of statistics. McGraw-Hill, New York.

Tekauz, A. and Z.A. Patrick. 1974. The role of twig infections on the incidence of perennial canker of peach. Phytopathology 64:683-688.

Wensley, R.N. 1964. Occurrence and pathogenicityof Valsa (Cytospora) species and other fungi associated with peach canker in southern Ontario. Can. J. Bet. 42:841-857.

Wisniewski, M., A.L. Bogle, and C.L. Wilson. 1984. Histopathology of canker development on peach trees after inoculation with Cytospora leucostoma. Can. J. Bet. 62:2804-2813.

Zimmerman, M.H. 1978. Hydraulic architecture of some diffuseporous trees. Can. J. Bet. 56:2286-2295. 